\title{
ATTACHMENT OF MAXILLARY LABIAL FRENUM IN NEPALESE CHILDREN
}

\author{
Dr. Sumita Upadhyay, ${ }^{1}$ Dr. Neeta Ghimire ${ }^{2}$ \\ ${ }^{1}$ Lecturer, Dept of Pedodontics, Kathmandu University School of Medical Sciences, Dhulikhel \\ ${ }^{2}$ Assistant Professor, Dept of Pedodontics, BP Koirala Institute of Health \& Sciences, Dharan
}

Correspondence : sumitadhungana@yahoo.com

\section{ABSTRACT}

Objective: To determine the various types of maxillary labial frenum attachment in Nepalese children.

Materials and method: A cross sectional study was conducted in a total of 198 children of age ranging from 1 to 14 years who visited Dental Department of Dhulikhel hospital for routine dental treatment. Types of maxillary labial frenum attachment was recorded along with age and gender. Children were divided into two groups; age 1-7 and 8-14 years. Descriptive analysis was carried out to determine the frequency of frenum types. The relation of frenum with gender and frenum types between two groups were calculated using chi square test.

Result: The most common type was gingival attachment (61.1\%) and the least common was papillary penetrating type of frenum attachment (8.1\%). There was no significant difference in the frenum attachment between the two genders. Mucosal and gingival attachment was significantly higher in older age group whereas papillary and papillary penetrating was higher in younger age group.

Conclusion: Attachment of frenum in children changes according to age.

Key words: frenum, gingival, mucosal, papillary, penetrating

\section{INTRODUCTION:}

Frenum is a fold of mucous membrane consisting of highly vascularized connecting tissue covered with epithelium. It contains a variable amount of collagenous fibrous tissue and its size varies from individual to individual. Frenum is passive in its relationship with maxillary alveolar process and pattern of its related development depends on the growth and development of alveolar ridge.

It is often a concern when maxillary labialfrenum becomes prominent in children. Treatment is suggested when the attachment exerts a traumatic force on the gingiva causing the papilla to blanch when the upper lip is pulled or if it causes a diastema to remain after eruption of the permanent canines. ${ }^{2,3}$

An abnormal maxillary labial frenum attachment may complicate orthodontic therapy and can cause post orthodontic relapse. ${ }^{4}$ It may also interfere with oral hygiene, cause stripping of tissue from the neck of the tooth, restrict movement of lips, interfere with speech and may produce an undesirable cosmetic result. If so, treatment is indicated. ${ }^{2,5}$

In infants, tight maxillary frenum alone or in conjunction with ankyloglossia may interfere with proper latching with mother's breast ${ }^{6}$ and can contribute to caries developemnt in anterior teeth. ${ }^{7}$
Distribution of various types of maxillary labial frenum attachment in Nepalese population has not been studied yet. So, the purpose of this study was to determine the various types of attachment of maxillary labial frenum in children.

\section{MATERIALS AND METHOD:}

A cross sectional study was conducted in a total of 198 children of age ranging from 1 to 14 years who visited Dental Department of Dhulikhel hospital for routine dental treatment. Study was conducted within November 2011 to February 2012. The children did not have any systemic disease. Those children whose labial frenum and adjacent mucosa was affected by trauma, taking medicine affecting gingiva, with orofacial defects and whose frenum had undergone surgery were excluded from the study.

Examination was done in the dental chair under light by a single examiner after taking verbal consent. Lip was gently stretched in horizontal direction away from the alveolar process. Maxillary labial frenum were divided into four types according to the classification given by Placek et al. ${ }^{8}$

Mucosal: Frenum inserting up to and including the mucogingival junction with no evidence of crossing into 
the attached gingiva, i.e. the stretched frenum did not appear to elevate the keratinized tissue.

Gingival: Frenum inserting into the attached gingiva and not extending coronal to the line demarcating the base of the midline papilla. The line demarcating the base of the midline papilla was defined as the line connecting the gingival zeniths of the two central incisors.

Papillary: Frenum inserting coronal to the line demarcating the base of the midline papilla without any visible evidence of frenum extension to the palatal aspect or of blanching anywhere on the palatal aspect of the midline papilla or on the incisive papilla, even when further tension was applied to the frenum.

Papillary penetrating: Frenum inserting coronal to the line demarcating the base of the midline papilla combined with visible evidence of frenum extension to the palatal aspect or of blanching anywhere on the palatal aspect of the midline papilla or on the incisive papilla when further tension was applied to the frenum.

Age, gender and frenum types were recorded for each individual. Children were divided into two groups; first group was from age 1-7 years and another group was from 8-14 years.

\section{Statistical analysis:}

Statistical analysis was done using SPSS 11.5. Descriptive analysis was carried out to determine the frequency of frenum types. The relation of frenum type with age group was calculated using chi square test. Statistical significance was set at $p<0.05$.

\section{RESULT:}

A total of 198 children with 101 (51\%) male and 97 (49\%) female were examined with mean age of $8.6 \pm 3.6$. The distribution of frenum attachment among those children is given in table 1 , graph 1 . The most common finding was gingival attachment (61.1\%) followed by papillary (17.2\%), mucosal (13.6\%)and the least common was papillary penetrating type of frenum attachment (8.1\%).

Those children were divided into two groups. First group were of the age between 1-7 years and second were of the age between 8-14 years. In both groups gingival attachment was higher than other types. While comparing between the two groups; mucosal and gingival attachment was significantly higher in older age group where as papillary and papillary penetrating type was higher in younger age groups $(p<0.05)$ (Table 2$)$.

Table 1. Distribution of different types of maxillary labial frenum attachments

\begin{tabular}{|l|c|c|}
\hline \multicolumn{1}{|c|}{ Frenum } & Frequency & Percentage \\
\hline Mucosal & 27 & 13.6 \\
\hline Gingival & 121 & 61.1 \\
\hline papillary & 34 & 17.2 \\
\hline Papillary penetrating & 16 & 8.1 \\
\hline \multicolumn{1}{|c|}{ Total } & $\mathbf{1 9 8}$ & $\mathbf{1 0 0}$ \\
\hline
\end{tabular}

Table 2. Comparison of types of frenum between two groups

\begin{tabular}{|c|c|c|c|c|c|}
\hline \multirow{2}{*}{ Groups } & \multicolumn{4}{|c|}{ FRENUM TYPE } & \multirow{2}{*}{ Total } \\
\cline { 2 - 5 } & mucosal & gingival & papillary & $\begin{array}{c}\text { papillary } \\
\text { penetrating }\end{array}$ & \\
\hline \multirow{2}{*}{$\begin{array}{c}\text { Group 1 } \\
(1-7 \text { Years })\end{array}$} & 7 & 41 & 28 & 12 & 88 \\
\hline $\begin{array}{c}\text { Group 2 } \\
(8-14 \text { Years })\end{array}$ & $18 \%$ & $46.6 \%$ & $31.8 \%$ & $13.6 \%$ & $100.0 \%$ \\
\hline$p$-value & 0.03 & 80 & 6 & 4 & 110 \\
\hline
\end{tabular}




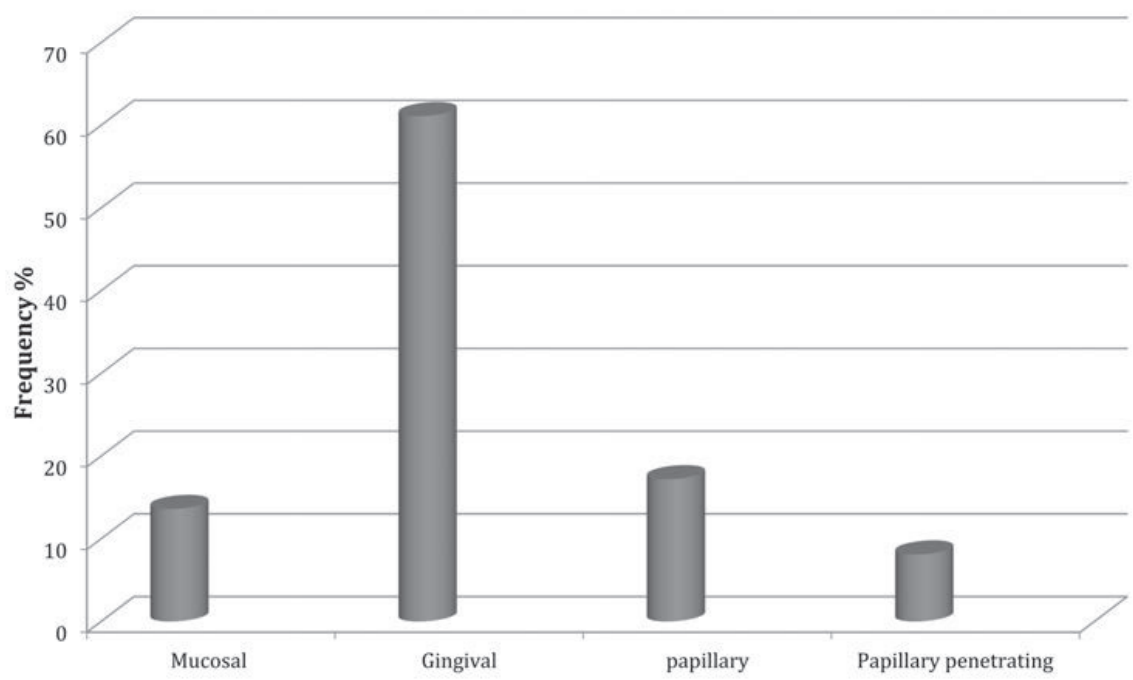

Graph 1. Distribution of different types of maxillary labial frenum attachments

\section{DISCUSSION:}

This was a cross sectional study done among Nepalese children attending Dental Department of Dhulikhel Hospital to assess the distribution of different types of maxillary labial frenum attachment. The most common finding was gingival type of frenum attachment and the least common was papillary penetrating type. Similar result was detected in other studies also.

Bergese did a study of frenum attachment in 428 Italian children aged 9-12 years and found that, in $58.2 \%$ the frenum was in attached gingiva. ${ }^{9}$

Kaimenyi in a study of 1802 children of Kenya aged between 4-16 years found that the commonest location of labial frenum attachment in the maxillary arch was in attached gingiva (50\%). None of the children had frenum attachment on the interdental papilla. ${ }^{10}$

When comparing between two groups, mucosal and gingival attachment was higher in older age group of children (8-14 years) whereas papillary and papillary penetrating was higher in younger age group of children (1-7 years). In both the groups, gingival attachment was higher than other types.

The result of a study done by Boutsi EA, Tatakis DN is also consistent with the result of the present study. Placek's classification was used to determine the frenum attachment in 226 children. The most common type was gingival attachment (41.6\%). The prevalence of the mucosal attachment was $10.2 \%$, papillary $22.1 \%$, and papillary penetrating $26.1 \%$. Children with mucosal type frenum were the oldest, while children with papillary penetrating type frenum were the youngest. There was also no gender difference in the frenum type. ${ }^{11}$

Jan' czuk and Banach did a study in 1542 Polish teens of age 15-17 years and found that the most common type of attachment was mucosal (39\%), followed by the gingival type (36\%). Papillary penetrating type was the least among all (5\%). ${ }^{12}$

Frenum may change from low to medium or high attachments, but only to a higher level of attachment. ${ }^{1}$

The superior labial frenum begins to form in the fetus at the tenth week of gestation. By the third month in utero the tectolabial frenum of the fetus is morphologically similar to the abnormal frenum of post natal life, which extends as a continuous band of tissue from the tuberculum on the inner side of the lip over and across the alveolar ridge to be inserted in the palatine papilla.

Before birth, the two lateral halves of the alveolar ridge unite and the continuous band of tissue becomes totally enclosed by bone. It is divided into a palatal portion (palatine papilla) and a labial portion (superior labial frenum) by this closure.

With time the frenum appears to recede up the labial surface of the alveolar process. This movement actually is relative during the primary dentition, as new bone deposits increase the height of the alveolar ridge while the frenal attachment remains in place. With the eruption of the permanent maxillary central incisors, the maxillary arch enters another period of vertical growth acceleration. ${ }^{13}$

Thus, attachment of the frenum in children will shift to a more apical position with the increasing age ${ }^{11}$ and this is revealed in present study also.

\section{CONCLUSION:}

In children age consideration is very important in deciding the treatment options for frenum and the difference in gender does not have significance in the type of frenum attachment. 


\section{REFERENCES:}

1. Popovich F, Thompson GW, Main PA. The maxillary interincisaldiastema and its relationship to the superior labial frenum and intermaxillary suture. Angle Orthod 1977; 47: 265-271.

2. Gkantidis N, Kolokitha OE, Topouzelis N. Management of maxillary midline diastema with emphasis on etiology. J Clin Ped Dent 2008;32(4):265-72.

3. Griffen AL. Periodontal problems in children and adolescents. In: Pinkham JR, Casamassimo PS, Fields HW Jr, McTigue DJ, Nowak AJ, eds. Pediatric Dentistry: Infancy through Adolescence. 4th ed. St. Louis, Mo: Elsevier Saunders; 2005:417.

4. Edwards JG. The diastema, the frenum, the frenectomy: a clinical study. Am J Orthod 1977; 71:489-508.

5. McDonald RE, Avery DR, Hartsfield JK. Acquired and developmental disturbances of the teeth. In: Dean JA, Avery DR, McDonald RE, eds. McDonald and Avery's Dentistry for the Child and Adolescent. 9th ed. Maryland Heights, Mo: Mosby Elsevier; 2011:11920.

6. Wiessinger D, Miller M. Breast feeding difficulties as a result of tight lingual and labial frena. A case report. J Human Lact 1995;11(4):313-316.

7. Kotlow LA. The influence of the maxillary frenum on the development and pattern of dental caries on anterior teeth in breastfeeding infants: prevention, diagnosis, and treatment. J Hum Lact 2010; 26:304-308.

8. Placek M, Skach M, Mrklas L. Significance of the labial frenum attachment in periodontal disease in man. Part I. Classification and epidemiology of the labial frenum attachment. J Periodontol 1974; 45:891-894.

9. Bergese F. Research on the development of the labial frenum in children of age 9-12 (in Italian). Minerva Stomatol 1966; 15:672-676.

10. Kaimenyi JT. Occurrence of midline diastema and frenum attachments amongst school children in Nairobi, Kenya. Indian J Dent Res 1998; 9:67-71.

11. Elizabeth A. Boutsi \& Dimitris N. Tatakis. Maxillary labial frenum attachment in children. Int J Pediatr Dent 2011;21:284-288.

12. Jan' czuk Z, Banach J. Prevalence of narrow zone of attached gingiva and improper attachment of labial frena in youths. Community Dent Oral Epidemiol 1980;8:385-386.

13. Huang WJ. The midline diastema: a review of its etiology and treatment. Pediatr Dent 1995;17(3):171-179. 